DOI $10.31168 / 0440-4.38$

\title{
THE BULGARIAN \\ REVOLUTIONARY ROMANTIC POET, CHRISTO BOTEV ${ }^{1}$
}

\begin{abstract}
:
This paper deals with Christo Botev (1848-76), a famous Bulgarian revolutionary, romantic poet, and publicist. He lived only 28 years, but left a deep impression not only on the history of the national liberation struggle of the Bulgarians against the Turkish yoke, but also in the history of the Bulgarian and, more widely, world literature. This applies both to his brilliant revolutionary romantic poetry and his journalism. Botev's first and the only book, "Songs and Poems by Botev and Stambolov", was published in 1875 in Bucharest. He published in it just 20 verses, but they brought him immortality. The poet did not live long. The following year, when the Bulgarians rebelled against the Turks, he hurried to their aid. Together with a detachment of about 200 people, he seized an Austrian steamer on the Danube and forced the captain to moor it on the Bulgarian coast. The detachment began to be pursued by the Turks, and after three days the poet was hit by a bullet from a Turkish sniper. The poetry of Botev belongs not only to the Bulgarian people, but also to all mankind.
\end{abstract}

\section{Keywords:}

Bulgaria, Christo Botev, national revival, Bulgarian folklore, poetry, revolutionary, romanticism, journalism.

АнНОтация: М.Г. СмОЛЬЯНИНОВА. «БОЛГАРСКИЙ РЕВОЛЮЦИОННЫЙ ПОЭТ-РОМАНТИК ХРИСТО БОТЕВ».

В работе речь идет о Христо Ботеве (1848-76) - известном болгарском революционере, поэте-романтике, публицисте. Он прожил всего 28 лет, но оставил глубокий след не только в истории национально-освободительной борьбы болгар против турецкого ига, но и в истории болгарской и - шире - мировой литературы. Это касается как его гениальной революционно-романтической поэзии, так и его публицистики. Первая и единственно прижизненная книга Ботева «Песни и стихотворения Ботева и Стамболова» была издана 1875 г. в Бухаресте. В ней он опубликовал всего 20 стихотворений, но они принесли ему бессмертие. Поэт прожил недолго. На следующий год, когда болгары восстали против турок, он поспешил им на помощь. Вместе с отрядом около 200 человек он захватил на Дунае австрийский пароход и заставил капитана причалить к болгарскому берегу. Отряд стали преследовать турки, и через три дня поэта сразила пуля турецкого снайпера. Поэзия Ботева принадлежит не только болгарскому народу, но и всему человечеству.

\section{Ключевые слова:}

Болгария, Христо Ботев, национальное возрождение, болгарский фольклор, поэзия, революционный романтизм., публицистика.

\footnotetext{
1 The work was carried out with the financial support of the RFBR (grant № 18-512-76004).
} 
hristo Botev, great Bulgarian revolu-
tionary romantic poet and journalist, whose works have been translated into 33 languages. He was born during the era of the Bulgarian national revival, when the country's struggle intensified against the centuries-old Turkish yoke. His studies in Russia and the controversy between the Russian liberals and the revolutionary democrats greatly influenced the formation of his worldview. He was especially fascinated by the ideas of the Russian revolutionaries M. A. Bakunin and S. G. Nechaev. After graduating from gymnasium in Odessa in 1866, Botev taught for several months in the Bessarabian village of Zadunayevka in a school for children of Bulgarian immigrants. His father's illness forced him to return to his hometown of Kalofer in Bulgaria, where he continu-

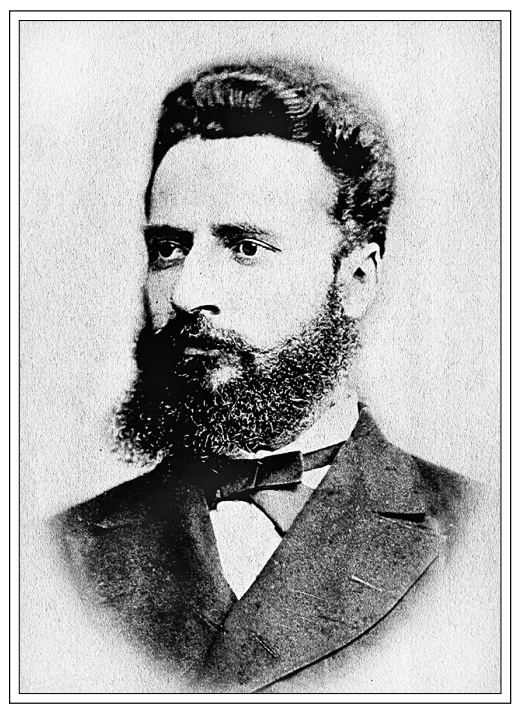

Christo Botev ed to teach, while at the same time preaching revolutionary ideas. This period, however, did not last long because of the threat of arrest by Turkish authorities. In the fall of 1867 , Botev moved to Romania, where many Bulgarian immigrants were living.

There he met many prominent figures of the Bulgarian national revival: playwright Dobri Voynikov, writers Ivan Vazov and Lyuben Karavelov, Bulgarian freedom fighters Vasil Levski, Hadzhi Dimitar and Stefan Karadzha. In the summer of 1868, while gathering together with the "voivode" (military commander) Zh. Chernev to cross over the Danube into Bulgaria to fight for the liberation of the fatherland, Botev wrote the poem At Parting, in which he prophetically predicted his fate.

However, that campaign never took place because of Zh. Chernev's arrest; destiny thus presented Botev with eight more years of life. In Romania the poet earned his daily bread by teaching and publishing articles in numerous emigrant newspapers. He had barely enough to live on and survived, half starving, in awful misery, wearing threadbare clothing. In the winter, together with Vasil Levski, he lived in a dilapidated windmill near Bucharest. Despite all these hardships, they remained undaunted. Botev was struck by Levski's resilience, energy and belief in the ultimate victory of the revolution. The latter managed to create an entire network of revolutionary committees throughout Bulgaria. In 1873, when the Turks captured and hung this fearless revolutionary, Botev responded to this terrible news with his brilliant poem The Hanging of Vasil Levski.

In April 1876 the Bulgarians rose up against the Turks, and Botev rushed to their aid. On 16 May of the same year, at the head of a "cheta" (a group usually 
numbering about 20-50 people), he seized the Austrian steamship "Radetsky" on the Danube and forced the captain to dock at the village of Kozloduy on the Bulgarian coast. From aboard the steamship, Botev sent telegrams to European newspapers, informing them of his group's campaign and expressing his hope that civilized nations would support the Bulgarians in their fight for freedom.

Then, as if having a presentiment of his own death and wanting to be on the safe side, he sent a letter to his wife Veneta and daughter Ivanka. In another letter from aboard the steamship, directed to his revolutionary comrades, Botev wrote of the joy filling his soul and giving him the strength of a lion in the impending struggle for freedom of the fatherland. According to him, this joy was immense, because the hope that he had expressed in the lines of his poem My Prayer had already begun to be realized.

Turkish military groups began to pursue Botev's cheta, which had moored on the Bulgarian coast. After three days of fighting, the cheta had moved far inland, but on 20 May 1876 the life of the poet came to an abrupt end. On a mountain peak near Vratsa, Botev was struck by the bullet of a Turkish sniper. After the death of their leader, the remaining cheta members being pursued by the Turks quickly dispersed.

Botev lived just 28 years, but he left a deep mark not only on the history of the Bulgarians' struggle for national liberation against the Turkish yoke, but also on the history of Bulgarian and, more broadly, European literature. This applies to both Botev's revolutionary romantic poetry and his journalism.

Botev wrote his first poem, To my Mother, in Russia; it was published in 1867 in the newspaper Guyda ("The Bagpipe"). This poem and his other poetic works were written from his heart. In his poetry, the arbitrariness of the Turks and national oppressors was usually resisted by "hayduks": noble robbers who both sought to revenge offenses committed against the people and to restore vital justice. The popular movement of hayduks was glorified by the poet in his poems and the ballads Fugitive, Hadzhi Dimitar, At Parting and A Dark Cloud is Coming.

Botev managed to rise to creative heights previously unknown in Bulgarian poetry due to the close connection of his works with folklore. He absorbed it together with the milk of his mother, who knew more than 300 national songs and often sang them to him. This national spirit imbues not only the figurative system of Botev's poetics but also the rhythm of his verses. As someone who reinvented folkloric images, he created innovative, original poetry, which came to be regarded as the pinnacle of Bulgarian literature and belonging among the greatest achievements of world poetry.

This is most brilliantly illustrated by one of the poet's ballads, Hadzhi Dimitar. This work was dedicated to the feat of Hadzhi Dimitar Asenov, who in 1868 led a campaign of his revolutionary compatriots to Bulgaria with the purpose of inciting rebellion. Elements of romantic imagery are combined with realistic depictions. The poet's grief over the death of Hadzhi Dimitar, who died fighting for the freedom of the people, was boundless. All of nature seeks to alleviate 
the suffering of the dying "yunak" (daredevil): an eaglet uses its wing to shield him from the scorching sun, a wolf licks his wounds, a free falcon and beautiful "samodivy", legendary and romantic creatures embodying people's dreams of eternal beauty and youth, mourn over him. In the ballad, the heavy, tragic tune of reaper slaves develops into a passionate, pathetic anthem of the Balkan mountains, glorifying the immortality of the fighters who sacrificed their lives for the freedom of the people.

One can clearly trace folkloric romantic motifs as well as realistic streams in Botev's works. Even his early poems are distinguished by their passionate citizenship; the poet was oppressed by the moral deafness of many Bulgarians who did not hear the "cries of the people." These features also appeared in his later verses (Elegy, Struggle, St George's Day and In the Tavern), which depicted the sufferings of the Bulgarians and exposed Turkish slavery.

Botev's brilliant journalism provided a striking example of his civic consciousness, unwillingness to concede to oppressors and of his qualities as a national tribune. In Romania he cooperated with the Bulgarian emigrant newspapers, Baraban ("The Drum"), Dunayskaya zarya ("The Danube Dawn"), Svoboda ("Freedom") and Nezavisimost ("The Independence"). He also issued his own newspapers: "The Word of the Bulgarian Emigrants" (1871), Budilnik ("The Alarm Clock," 1873), Zname ("The Banner," 1875) and Nov bulgarsky vestnik ("The New Bulgarian Herald," 1876). A series of his feuilletons, Whether You Know Who are We, represents a satirical panorama of life in the Ottoman Empire. Such works as the pamphlet Ridiculous Crying, the articles Whether the Church Issue is Resolved?, People Yesterday, Today and Tomorrow, along with a series of political feuilletons, The Message from the Sky, and a review, The Political Winter, are among Bulgarian journalism's highest achievements of that time.

Journalism was something Botev subordinated to his main purpose in life: the liberation of Bulgaria. As a troubadour of freedom, he reproached the Bulgarian people for being too long-suffering and pointed to the availability of forces, means and patriotism to attain freedom. Along with this he was worried about the dearth of broad revolutionary propaganda which would unite the Bulgarians' disparate revolutionary actions against the Turks together and would point the people to the ultimate noble goal - liberation from foreign despotism.

Despite its many merits, Botev's journalism is far surpassed by his poetry. Only a few dozen of his verses have survived (the majority of them were published in the book Songs and Poems by Botev and Stambolov, Bucharest, 1875), but they brought him immortality. He can be compared to the English romantic poet Byron, who died half a century before battling against the Turks for the freedom of the Greeks. The poetry of these two creative geniuses belongs not just to the people of England and Bulgaria, but to all of humanity. 


\section{BIBLIOGRAPHY}

Derzhavin N.S. Christo Botev: poet - revoliutsioner (1848-1876). Moscow-Leningrad, 1948.

\section{ILLUSTRATIONS}

1. Ivanka, mother of Christo Botev.

2. Christo Botev. Portrait.

3. Cover of the only lifetime collection of the poet "Songs and poems by Christo Botev and Stefan Stambolov", published in 1875 in Bucharest.

4. A letter from Christo Botev to his wife Veneta, sent by him on 17 May 1876 from the ship "Radetsky" shortly before his death.

5. Facsimile of Botev's letter to T. Peyev, a comrade in arms in the revolutionary struggle.

6. Monument to Christo Botev in Vratsa.

7. Research of Christo Botev's work by Bulgarian scholars I. Undzhiev and Ts. Undzhieva. Sofia, 1975. 